\title{
Carpal tunnel syndrome and subsequent rheumatoid arthritis in the 'fibrositis' syndrome
}

\author{
ANTHONY J. RICHARDS \\ From the Department of Rheumatology, Worthing Hospital, Worthing, West Sussex BN11 2DH
}

SUMMARY Eight of 11 patients who satisfy Smythe's criteria for the 'fibrositis' syndrome have subsequently developed carpal tunnel syndrome. Six of the 8 patients have gone on to develop an inflammatory polyarthritis, 3 of whom are seropositive and satisfy the criteria for classical rheumatoid arthritis. The relationship between the 'fibrositis' syndrome and rheumatoid arthritis is not clear, but the additional complication of carpal tunnel syndrome in 'fibrositis' points to certain patients with 'fibrositis' developing an inflammatory polyarthritis of rheumatoid type. Acceptance on a definition of 'fibrositis' would enable further prospective studies to take place, but at present the term is used to describe many other nonarticular conditions that do not satisfy Smythe's criteria.

Fibrositis can be interpreted as being a condition of generalised aches and pains in which the patient complains bitterly of discomfort, may have tender areas or trigger spots, is often depressed, and in whom investigations reveal no abnormality. All rheumatologists see patients who fit into this category of nonarticular rheumatism, yet there is no agreement on the precise terminology that should be applied to this form of rheumatism.

In this paper fibrositis is used to describe the 'fibrositis' syndrome as defined by Smythe. ${ }^{1}$ Eleven patients satisfying Smythe's criteria (Table 1) have been seen over a 5-year period. The 11 patients attended a routine rheumatology outpatient clinic at Worthing Hospital and represented $0.17 \%$ of new referrals from general practitioners in the Worthing District to the author during that period.

The criteria for the diagnosis of 'fibrositis' include 14 areas of deep tenderness, which are located in the trapezius, the second costochondral junctions, the lateral epicondyles, the supraspinatus muscle, the

Table 1 Criteria for the diagnosis of the 'fibrositis' syndrome (Smythe ${ }^{1}$ )

1. Widespread aching $>3$ months' duration

2. Local tenderness at $\mathbf{1 2}$ or more of $\mathbf{1 4}$ specified sites

3. Skin roll tenderness over the upper scapular region

4. Disturbed sleep, with morning fatigue and stiffness

5. Normal ESR, aspartate transaminase (SGOT), RA factor, antinuclear factor (ANF), muscle enzymes and sacroiliac $x$-ray films

Accepted for publication 21 June 1983

Correspondence to Dr A. J. Richards. lower cervical and lower lumbar regions of the spine, the gluteus medius, and the medial fat pad of the knee. Apart from the spinal regions the sites of tenderness are bilateral, and many other areas not included in the 14 specified sites may also be tender in 'fibrositic' individuals.

\section{Patients and methods}

The details of the 11 patients are shown in Table 2 . There were 8 women and 3 men. The age range at the time of diagnosis of 'fibrositis' was from 27 to 44 years, with a mean of 35.54 years. None of the 11 patients had any signs of inflammatory arthritis at the initial consultation, which included a complete physical examination. A routine blood count, erythrocyte sedimentation rate (ESR), and estimations of rheumatoid factor and serum thyroxine (T4) were performed on all patients. The initial results revealed no abnormality.

\section{Results}

The 11 patients were followed up prospectively, and 8 patients (cases 1 to 6 and cases 8 and 10) developed carpal tunnel syndrome (CTS). The dominant hand was usually involved, but in 2 patients (cases 3 and 8 ) the onset was bilateral.

The diagnosis of CTS was made according to the following criteria: sensory signs in the median nerve distribution, thenar muscle wasting or weakness, and a median nerve motor latency at the wrist greater than $4.5 \mathrm{~ms}$. The serum T4 was in the normal range 
Table 2 Cases of 'fibrositis' syndrome

\begin{tabular}{|c|c|c|c|c|}
\hline \multicolumn{2}{|c|}{ Case no. /Sex } & \multirow{2}{*}{$\begin{array}{l}\begin{array}{l}\text { Age at } \\
\text { diagnosis* }\end{array} \\
28\end{array}$} & \multirow{2}{*}{$\begin{array}{l}\text { Approximate interval between } \\
\text { 'fibrositis' diagnosis and CTS } \\
6 \text { months }\end{array}$} & \multirow{2}{*}{$\begin{array}{l}\text { Predominant } \\
\text { hand affected }\end{array}$} \\
\hline 1 & F & & & \\
\hline$† 2$ & $\mathrm{~F}$ & 34 & 10 months & Right \\
\hline+3 & $\mathbf{F}$ & 42 & 3 months & Both \\
\hline+4 & $\mathbf{F}$ & 27 & 2 months & Right \\
\hline 5 & $\mathbf{F}$ & 31 & 8 months & Right \\
\hline+6 & $\mathbf{F}$ & 38 & 3 months & Right \\
\hline 7 & $\mathbf{F}$ & 43 & & \\
\hline+8 & $\mathbf{M}$ & 38 & 6 months & Both \\
\hline 9 & $\mathbf{M}$ & 27 & & \\
\hline$\dagger 10$ & F & 44 & 2 months & Left \\
\hline 11 & $\mathbf{M}$ & 39 & & \\
\hline
\end{tabular}

* Average age $35 \cdot 54$.

+ Subsequent rheumatoid arthritis.

Table 3 Patients with 'fibrositis' and CTS who developed polyarthritis

\begin{tabular}{cccccc}
\hline Case no./Sex & Age & Initial ESR & Latest ESR & RA latex \\
\hline 2 & F & 34 & 14 & 18 & Neg \\
3 & F & 42 & 18 & 38 & Pos \\
4 & F & 27 & 6 & 16 & Neg \\
6 & F & 38 & 15 & 22 & Neg \\
8 & M & 38 & 10 & 27 & Pos \\
10 & F & 44 & 19 & 48 & Pos \\
Average & $37 \cdot 16$ & $13 \cdot 66$ & $28 \cdot 16$ & \\
\hline
\end{tabular}

for the 8 patients with CTS. The approximate interval between the diagnosis of 'fibrositis' and the development of CTS varied between 2 and 10 months, an average of 5 months (Table 2).

Subsequently 6 of these 8 patients with CTS developed an inflammatory polyarthritis (Table 3 ), but it is difficult to pinpoint with any accuracy the exact time when this occurred, as the arthritis developed insidiously. The 6 patients satisfied the American Rheumatism Association criteria for rheumatoid arthritis (RA), ${ }^{2}$ though only 3 were seropositive and fulfilled the criteria for classical RA (cases 3, 8, and 10). These 3 patients had a higher ESR at the time of writing than the three patients who were seronegative and who satisfied the criteria for definite RA (cases 2, 4, and 6). The arthritis principally involved the hands and wrists, making the symptoms of CTS much worse. All patients required injections of hydrocortisone acetate into one or both carpal tunnels, but none required surgical decompression of the median nerves.

A careful watch was kept on the other 2 patients with CTS (cases 1 and 5) and the 3 patients with neither CTS nor RA (cases 7, 9, and 11) who had not developed any additional complication. All 11 patients continued to be seen at regular intervals in the outpatient department by the author.

\section{Discussion}

This paper highlights a problem in diagnosis. It could be argued that this series merely represents a crosssection of patients, some with 'fibrositis', and some with undiagnosed RA, as it is well known that CTS may be the first presenting feature of RA. Perhaps if nerve conduction studies had been carried out on the 11 patients at the time of the initial consultation the diagnosis of CTS might have been made earlier. Nerve conduction studies shortly after CTS was diagnosed revealed a prolonged motor latency for the median nerve at the wrist of more than $4.5 \mathrm{~ms}$ in the 8 patients with this complication. The fact remains, however, that this was a prospective study adopting Smythe's criteria for 'fibrositis', yet only 11 such patients were diagnosed in a 5-year period, though many times that number were seen with CTS who did not meet the criteria for the 'fibrositis' syndrome (Table 1). Of these 8 patients 6 have developed an inflammatory polyarthritis, 3 of whom are seropositive (cases 3, 8, and 10).

The 'fibrositis' syndrome as described by Smythe ${ }^{1}$ is an example of what he calls a 'pain amplification syndrome'. Other examples he refers to are the reflex dystrophy syndrome, the tender skins of steroid therapy, and narcotic withdrawal. The prescription of 
hypnotics, analgesics, or nonsteroidal antiinflammatory drugs, and physiotherapy, together with constant reassurance, was the main basis of treatment. Additional complications such as CTS or RA required certain adjustments to treatment, such as injections of hydrocortisone into the carpal tunnels, night splinting, and, in the case of RA, the use of gold or penicillamine. No studies on psychological factors were carried out, but it has been shown that the majority of patients with 'fibrositis' are more psychologically disturbed than patients with RA. ${ }^{3} \mathrm{~A}$ plea for the abandonment of the term 'fibrositis' has recently been made by Reynolds, ${ }^{4}$ who suggests that Smythe's 'fibrositis' is in fact a mixture of myofascial pain, panniculosis, and psychogenic rheumatism. If this is so, recent studies of psychological disturbance in 'fibrositis' may be meaningless.
The author would agree that, although the term 'fibrositis' may not imply a real diagnosis, it has been used in this study strictly according to Smythe's criteria. ${ }^{1}$ A clearer understanding of what rheumatologists mean by 'fibrositis' is urgently needed, though Smythe has defined what he means by this term.

\section{References}

1 Smythe H A. 'Fibrositis' as a disorder of pain modulation. In: Clinics in rheumatic diseases. Eastbourne: Saunders, 1979; 5: 823-32.

2 Ropes M W, Bennett G A, Cobb S, et al. Revision of diagnostic criteria for rheumatoid arthritis. Bull Rheum Dis 1958; 9: 175-6.

3 Payne T C, Leavitt F, Garron D C, et al. Fibrositis and psychologic disturbance. Arthritis Rheum 1982; 25: 213-7.

4 Reynolds M D. The definition of fibrositis. Arthritis Rheum 1982; 25: 1506-7. 